\title{
Radon and thoron daughter activities in the environment of the King George Island (West Antarctica)
}

\author{
Andrzej Tomasz Solecki \\ Institute of Geological Sciences Wrockaw Univeristy, Wrockaw, Poland \\ Department of Antarctic Biology Polish Academy of Sciences, Warsaw, Poland
}

\begin{abstract}
Results of 253 gamma spectrometric analyses of radon daughters in soil and bedrocks of the King George Island (West Antarctica) are presented. Measured values range from 0.1 to $58.4 \mathrm{~Bq} / \mathrm{kg}$, and from 4.9 to $75.5 \mathrm{~Bq} / \mathrm{kg}$ for ${ }^{214} \mathrm{Bi}$ and ${ }^{208} \mathrm{Tl}$ respectively, but most measurements fall in the lower part of this range due to predominantly basaltic character of the geological basement. Obtained gamma spectrometric data correspond well to very low soil gas radon content measured by means of Kodak LR115 being below $454 \mathrm{Bqm}^{-3}$. Low soil gas radon content and characteristic type of architecture is responsible for low indoor radon activity in Arctowski Station being as low as 10$15 \mathrm{Bqm}^{-3}$. The highest $105 \mathrm{Bqm}^{-3}$ indoor Rn activity has been measured in the greenhouse bungalow of the station. This increased value was probably connected with the presence of about $1000 \mathrm{~kg}$ of imported soil material in the greenhouse room of the bungalow. Local zones of increased uranium and thorium content, discovered as a result of radiometric mapping, can potentaily influence atmospheric radon used for meteorological interpretation.
\end{abstract}

Key words Antarctica - radon - uranium - thorium - spectrometry

\section{Introduction}

The area under investigation (fig. 1) is a part of the Shetland microplate which originated at the subducting Pacific margin of Gondwana and contains Cretaceous-Early Miocene island arc extrusives (mainly basalts and andesites) and intrusives (gabros, diorites, monzonites) (Birkenmajer et al., 1991). Oceanic basalts are normally of low uranium and thorium content. and atmospheric radon activity is extremly low over ocean-

Mailing address: Dr. Andrzej Tomasz Solecki, Institute of Geological Sciences Wrockaw Univeristy, pl. M. Borna 9, 50-204 Wrockaw, Poland; e-mail asol@ing.uni.wroc.pl ic island areas. In such a situation any migration of air from the continents, where radon activities are ten times higher can be easily detected, making radon a useful tracer of atmospheric circulation (see Lambert et al., 1970; Turekian et al., 1977; Reiter, 1978; Polian et al., 1986; Balkanski and Jacob, 1990; Jacob et al., 1997).

However, locally, even within oceanic islands, magmatic differentiates of andesitic and granodioritic character and hydrothermal zones occur. They can be enriched in uranium and thorium making them a significant local source of radon emmanation. This possibility should be taken into account in the case of any meteorological interpretation. A pioneering paper on radon activity in the King George Island Area published by Evangelista, Pereira (2002) did not contain elements of radiometric mapping, in spite of the consolidated geophysical experience of both authors probably because of logistic problems. Because this, mapping was performed during austral summer 2002/2003 by the present 


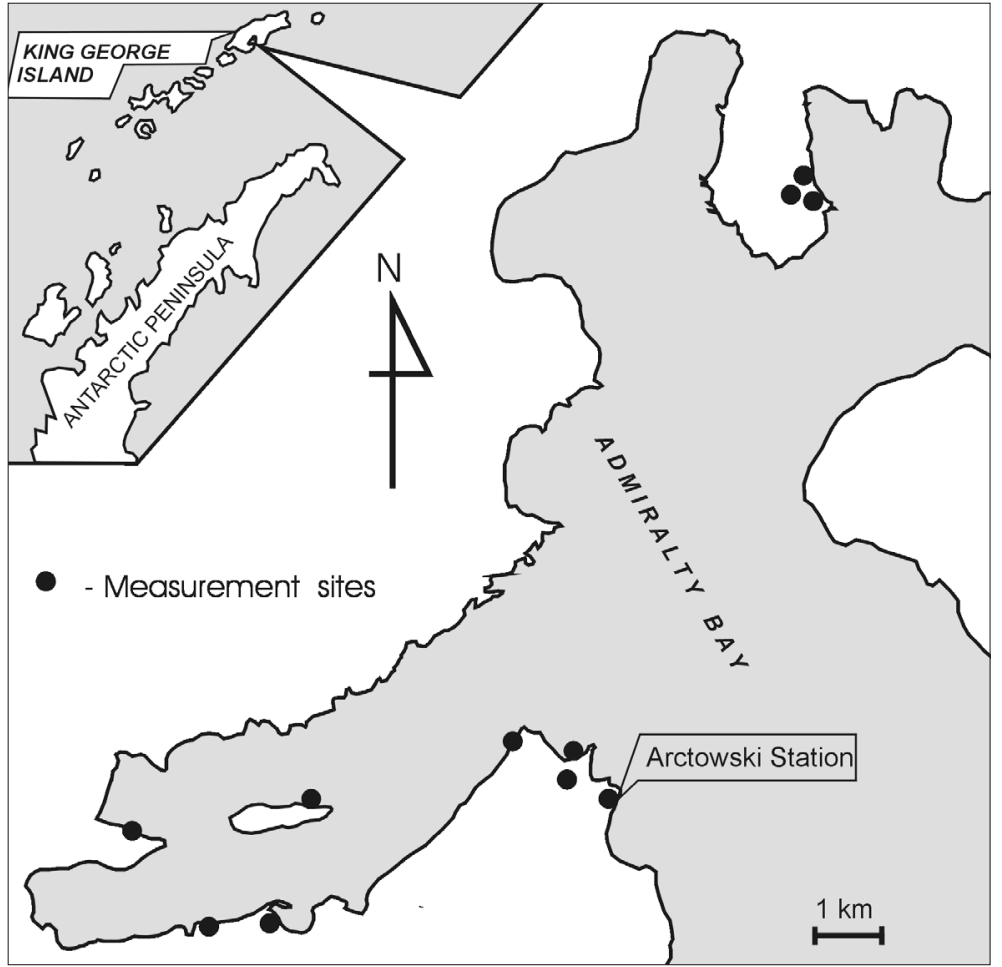

Fig. 1. Localisation of the study area, three northernmost sites are located in the Keller Peninsula close to Ferraz station.

Table I. Gamma ray spectrometer GR-320 energy window characteristics.

\begin{tabular}{cccccc}
\hline \hline Band & \multicolumn{2}{c}{ Radionuclide peak } & Channels & Energy window (keV) & Sensitvity \\
\hline $\mathrm{RO} / 2$ & ${ }^{40} \mathrm{~K}$ & $1460 \mathrm{keV}$ & $109-122$ & $1370-1570$ & $0.661 \mathrm{cps} / \%$ \\
$\mathrm{RO} / 3$ & ${ }^{214} \mathrm{Bi}$ & $1760 \mathrm{keV}$ & $129-142$ & $1660-1860$ & $0.067 \mathrm{cps} / \mathrm{ppm}$ \\
$\mathrm{RO} / 4$ & ${ }^{208} \mathrm{Tl}$ & $2620 \mathrm{keV}$ & $179-204$ & $2410-2810$ & $0.025 \mathrm{cps} / \mathrm{ppm}$ \\
\hline
\end{tabular}

author by means of a portable gammaspectrometer GR-320.

\section{Analytical method}

Measurements of bedrock radon daughter activity were performed using an Exploranium GR-320 gamma radiation spectrometer with the standard NaI (Tl) GPX-21A detector of $0.35 \mathrm{~L}$ volume. Calibration of the detector was performed by the manufacturer using traceable test pads. Impulses supplied by the detector units were classified using channels 70-204 of the 256 channels of the spectrometer covering the energy window 850-2810 keV.

Three bands (Regions of Interests ROI) corresponding to energy windows of radionu- 
clide peaks ${ }^{40} \mathrm{~K},{ }^{214} \mathrm{Bi}$ and ${ }^{208} \mathrm{Tl}$ were set up (table I).

The problem of stabilization of energy windows of channels was solved by means of continous measurement of caesium $662 \mathrm{keV}$ photons from internal source in the band $\mathrm{RO} / 1 \mathrm{cov}-$ ering channels 51-60 (600-730 keV).

Gain parameter responsible for fitting channels to energy windows was continously updated using the least-squares fit of a Gaussian caesium peak shape every time the 5000 level of Cs counts was exceeded. This ensured that system gain was always correct and selected channels corresponded to the desired energy windows.

Measured activities of radon and thoron daughters were recalculated into uranium and thorium concentrations (in ppm) assuming existence of equilibrium in uranium and thorium decay series, a common practice in this kind of measurements marked by eU and eTh notation instead of $\mathrm{U}$ and $\mathrm{Th}$. For each measurement the detector was deployed in the field using a geometry as close as possible to $2 \Pi$. Sampling time ranged from 15 to 30 min depending on local radionuclide content to reach statistically significant counts in all ROI's. Ambient temperature during measurements was in the range -2 to $+6^{\circ} \mathrm{C}$, well above the recommended limit of $-10^{\circ} \mathrm{C}$

Radon activity was measured by means of the Kodak LR115 solid state nuclear track detectors. In the case of indoor measurements detectors were placed on the wall at a height of $2 \mathrm{~m}$.
Soil-gas radon activity was measured in five sites at a depth of $20 \mathrm{~cm}$ and the detectors were fixed inside a plastic cap of $15 \mathrm{~cm}$ internal diameter. In both cases free air space around the detector was greater than $7.5 \mathrm{~cm}$ to avoid irradiation by plateout particles. Real soil with organic matter horizon (3 cm thick) existed only in one case in other cases physically weathered fine grained material of bedrock prevailed.

\section{Results}

Average measured bedrock radon and thoron daughter activity was 14.6 and 18.9 $\mathrm{Bq} / \mathrm{kg}$ for ${ }^{214} \mathrm{Bi}$ and ${ }^{208} \mathrm{Tl}$, respectively, reaching its maximum values 58.4 and $75.5 \mathrm{~Bq} / \mathrm{kg}$ for granodioritc dropstone (table II). In the case of basalts, ${ }^{214} \mathrm{Bi}$ activity was often below detection limit, while for ${ }^{208} \mathrm{Tl}$ the lowest recorded value was $4.9 \mathrm{~Bq} / \mathrm{kg}$. Trimodal distribution of the obtained data was especially well visible in the case of thoron activity (fig. 3). Three groups of radon activities $\left({ }^{214} \mathrm{Bi}\right): 4,16$ and $36 \mathrm{~Bq} / \mathrm{kg}$ visible in the fig. 2 corresponded to basement composed of: basalts, andesites and granodioritic quarzt lode, respectively. The same rocks in the case of thoron activity $\left({ }^{208} \mathrm{Tl}\right)$ data yielded three maximas: 4, 20 and $52 \mathrm{~Bq} / \mathrm{kg}$ (fig. 3). Quartz lodes of $2.8 \mathrm{ppm}$ eU and $12.6 \mathrm{ppm}$ eTh seem to be a potentialy high source of radon, and especially thoron emanation. Its outcrop tens of meters wide was covered with high

Table II. Mean values of Rn daughter activities for various rocks types.

\begin{tabular}{lccccc}
\hline \hline & $\begin{array}{c}{ }^{214} \mathrm{Bi} \text { activity } \\
\mathrm{Bq} / \mathrm{kg}\end{array}$ & $\begin{array}{c}{ }^{208} \mathrm{Tl} \text { activity } \\
\mathrm{Bq} / \mathrm{kg}\end{array}$ & $\begin{array}{c}\mathrm{eU} \text { ppm calculated } \\
\text { from }{ }^{214} \mathrm{Bi} \text { activity }\end{array}$ & $\begin{array}{c}\text { eTh ppm calculated } \\
\text { from }{ }^{208} \mathrm{Tl} \text { activity }\end{array}$ & $\begin{array}{c}\text { Number of } \\
\text { measurements }\end{array}$ \\
\hline Basalt & 5.6 & 8.7 & $0.45 \pm 0.07$ & $2.12 \pm 0.29$ & 35 \\
Lahar (tillite) & 13.7 & 18.5 & $1.10 \pm 0.07$ & $4.50 \pm 0.15$ & 24 \\
Cobble beach & 18.2 & 20.0 & $1.46 \pm 0.11$ & $4.87 \pm 0.27$ & 16 \\
Andesite & 21.0 & 25.4 & $1.69 \pm 0.12$ & $6.19 \pm 0.43$ & 11 \\
Tuffite-zeolite & 21.9 & 26.5 & $1.76 \pm 0.13$ & $6.45 \pm 0.32$ & 20 \\
Granodiorite & 58.4 & 75.5 & 4.70 & 18.4 & 1 \\
$\begin{array}{l}\text { Ezcurra fault zone } \\
\text { Keller peninsula }\end{array}$ & 19.4 & 23.3 & $1.56 \pm 0.15$ & $5.68 \pm 0.46$ & 8 \\
mineral vein & 35.2 & 51.9 & $2.83 \pm 0.12$ & $12.65 \pm 0.36$ & 12
\end{tabular}




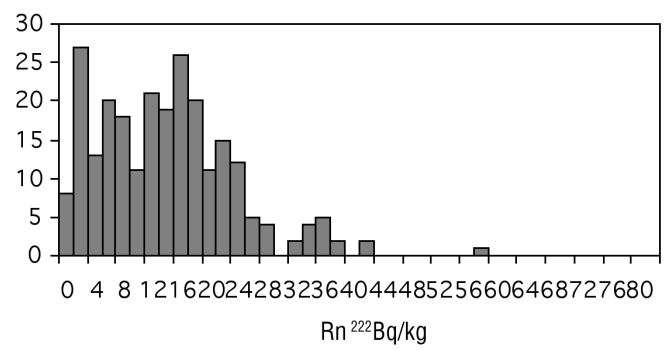

Fig. 2. Histogram of radon activity distribution.

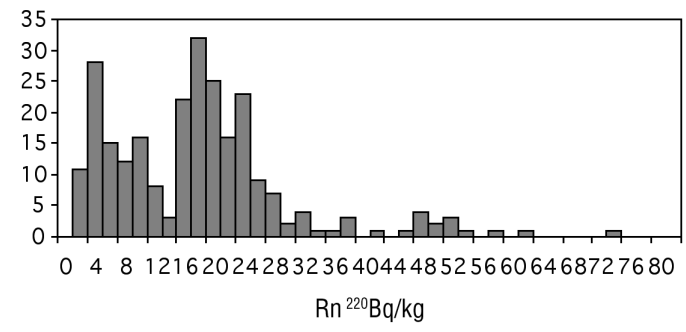

Fig. 3. Histogram of thoron activity distribution.

amounts of crushed material which resulted due to physical weathering in polar climate.

Locally significant chemical weathering was superimposed due to abundance of pyrite. All these factors resulting in a strong increase in porosity and permeability can be responsible for significant radon flux towards Brazilian Ferraz Station located few tens meters down slope.

The highest result of five measurements of $\mathrm{Rn}$ soil gas activity $454 \mathrm{Bqm}^{-3}$ was measured in the weathered volcanoclastic-zeolitic material of 21 and $26 \mathrm{~Bq} / \mathrm{kg}$ for ${ }^{214} \mathrm{Bi}$ and ${ }^{208} \mathrm{Tl} \mathrm{re}-$ spectively. Indoor radon activity values obtained were as low as $10-15 \mathrm{Bqm}^{-3}$ (five measurements) in social rooms of Polish Henryk Arctowski station.

The highest $105 \mathrm{Bqm}^{-3}$ indoor Rn activity was measured in the greenhouse bungalow of the station. This increased value was probably connected with the presence of about $1000 \mathrm{~kg}$ of imported soil material in greenhouse room of the bungalow.

\section{Conclusions}

Obtained results indicate that King George Island area is of extremely low $\mathrm{Rn}$ potential due to low uranium and thorium content and low emanation coefficient of the chemically unweathered bedrock material. Measured values are slightly lower than those based on 22 gamma-spectrometric measurements published by Evangelista and Pereira (2002), but a much better fit to Godoy et al. (1998) data and world scale data for areas of such a geology. However, the local increase in uranium and thorium concentration observed locally can result in significant radon flux in favourable meteorogical conditions. Rapid pressure changes connected with cyclones can promote radon flux from such zones (see Schery and Gaeddert, 1982), which can be interpreted as influx of remote continental air. From this point of view, results obtained at Brasilian Ferraz Station (Evangelista and Pereira, 2002) should be interpreted very carefully since it is located downslope of the quartz lode outcrop covered with a high dump of crushed and weathered rocky material of relatively high uranium and thorium content.

\section{Acknowledgements}

The author would like to thank Prof. S. Rakusa-Suszczewski and other colleagues from the Department of Antarctic Biology Polish Academy of Sciences for their kind support, help and companionship in the remote area of West Antarctica. The author is also grateful to Brazilian Colleagues form Ferraz Station for their kind hospitality. Research was partly funded by grant No. 2022/W/ING of the Institute of Geological Sciences Wroclaw University.

\section{REFERENCES}

BALKAnSKI, Y.J. and D.J. JACOB (1990): Transport of continental air to the Subantarctic Indian Ocean, Tellus, 42B (1), 62-75.

Birkenmajer, K., L. Francalanci and A. Peccerillo (1991): Petrological and geochemical constraints on the genesis of Mesozoic-Cenozoic magmatism of King George Island, South Shetland Islands, Antarctica, Antarctic Sci., 3 (3), 293-308. 
Evangelista, H. and E.B. Pereira (2002): Radon flux at King George Island, Antarctic Peninsula, J. Environ. Radioact., 61, 283-304.

Godoy, J.M., L.A. Schuch, D.J.R. Nordemann, V.R.G. Reis, M. Ramalho, J.C. Recio, R.R.A. Brito and M.A. Olech (1998): ${ }^{137} \mathrm{Cs},{ }^{226} \mathrm{Ra},{ }^{228} \mathrm{Ra}$ and ${ }^{40} \mathrm{~K}$ concentrations in 0-5 cm soil samples collected at several South Shetland Islands, J. Environ. Radioact., 41 (1), 33-45

JACob, D.J., M.J. Prather, P.J. Rasch, R. Shia, Y.J. Balkanski, S.R. Beagley, D.J. Bergman, W.T. Blackshear, M. Brown, M. Chiba, M.P. ChipperField, J. Grandpre, J.E. Dignn, J. Feichter, C. GenTHON, W.L. Grose, P.S. Kasibhatla, I. Koehler, M.A. Kritz, K. Law, E.J. Penner, M. Ramonet, C.E. Reeves, D.A. Rotman, D.Z. Stockwell, P.F.J. Van Velthoven, G. Verver, O. Wild, H. Yang and P. ZiMMERMANN (1997): Evaluation and intercomparison of global atmospheric transport models using
$222 \mathrm{Rn}$ and other short-lived tracers, J. Geophys. Res., 102 (D5), 5953-5970.

LAmbert, G., G. Polian and D. TAupin (1970): Existence of periodicity in radon concentrations and in the largescale circulation at latitudes between 40 and 70 south, J. Geophys. Res., 75, 2341-2345.

Polian, G., G. Lambert, B. Ardouin and A. Jegou (1986). Long-range transport of continental radon in subantarctic and antarctic areas, Tellus, 38B, 178-189.

ReITER, E.R. (1978): Atmospheric Transport Processes Part 4: Radiactive Tracers (Technical Information Center, US Department of Energy).

SCHERY, S.D. and D.H. GAEDDERT (1982): Measurements of the effect of cyclic atmospheric pressure variation on the flux of 222 Rn from the soil, Geophys. Res. Lett., 9 (8), 835-838

Turekian, K.K., Y. NozaKi and L.K. Benninger (1977). Geochemistry of atmospheric radon and radon products, Ann. Rev. Earth Planet. Sci., 5, 227-255. 